\title{
MONITORING MANGROVE UNTUK ESTIMASI POTENSI KARBON BIRU DI DUMAI, RIAU
}

\author{
Nuryani Widagtia**, Frida Sidik ${ }^{a}$, dan Novia Arinda Pradisty \\ ${ }^{a}$ Balai Riset dan Observasi Laut, BRSDM, KKP, \\ Jalan Baru Perancak, Jembrana, Bali, Indonesia \\ *Koresponden penulis: nuryani.widagti@kkp.go.id
}

\begin{abstract}
Abstrak
Mangrove menyediakan berbagai jasa ekosistem, salah satunya adalah sebagai penyerap dan penyimpan karbon biru. Perhitungan jumlah simpanan dan serapan karbon di hutan mangrove menjadi penting karena hutan mangrove di Indonesia memiliki simpanan karbon biru tertinggi di dunia. Informasi potensi karbon biru mangrove dapat diperoleh dari kegiatan monitoring mangrove yang dilakukan secara berkala. Dengan lokasi penelitian di Dumai, Riau, studi ini mengestimasi karbon yang disimpan dan diserap oleh pohon mangrove di tepi sungai dan dalam hutan. Struktur komunitas diketahui dengan menghitung Shannon-Wiener Index, sementara biomasa dan potensi simpanan karbon mangrove dihitung dengan persamaan alometrik khusus berdasarkan jenis. Jenis mangrove yang ditemukan di lokasi penelitian antara lain Rhizophora apiculata, Avicennia marina, Xylocarpus granatum, Bruguiera gymnorrhiza, Sonneratia alba, Lumnitzera racemosa, dan Nypa frutican, dimana Stasiun Tepi Sungai didominasi oleh Xylocarpus granatum (kisaran Ø 1.36-23.25 cm), sementara Rhizophora apiculata mendominasi stasiun di dalam hutan dengan kisaran $\varnothing 1.27$ $23.25 \mathrm{~cm}$. Laju pertumbuhan mangrove cukup beragam dan Avicennia marina memiliki laju tercepat. Hasil menunjukan bahwa dengan estimasi rata-rata biomasa mangrove sekitar $596.56 \mathrm{Mg} \mathrm{ha}^{-1}$ hutan mangrove di Dumai, Riau, berpotensi menyimpan karbon sebesar 285.24 $\mathrm{Mg} \mathrm{C}^{-1}$. Karbon yang tersimpan di Stasiun Dalam Hutan lebih besar (332.9 $\mathrm{Mg} \mathrm{C} \mathrm{ha}^{-1}$ ) dibandingkan dengan di Stasiun Tepi Sungai (237.58 $\mathrm{Mg} \mathrm{C}^{-}$ $\left.{ }^{1}\right)$. Apabila satu hektar hutan mangrove di Dumai, Riau, rusak atau hilang, maka potensi karbon yang dilepaskan sebesar $1046.83 \mathrm{Mg} \mathrm{CO}_{2} \mathrm{ha}^{-1}$, yaitu setara dengan jumlah $\mathrm{CO}_{2}$ yang terlepas dari pembakaran 524.82 ton batu bara.
\end{abstract}

Kata kunci: Biomasa, serapan karbon, hutan mangrove, Dumai, Riau

\begin{abstract}
Mangroves provide various ecosystem services, one of which is as a carbon sink and storage. The assessment of mangrove carbon stock and sequestration becomes a global concern especially for Indonesia's mangrove forests that store most of mangrove blue carbon in the world. Blue carbon potentials in mangroves can be estimated by assessing mangroves through periodic monitoring. Here, the study was undertaken in mangrove forests in Dumai, Riau, and aimed to assess the carbon stored and sequestered in mangroves located riverside and inside the forests. The forest structure was examined with the Shannon-Wiener Index, while biomass and potential carbon storage of mangroves calculated by specific allometric equations based on the species. The species found in the study site were Rhizophora apiculata, Avicennia marina, Xylocarpus granatum, Bruguiera gymnorrhiza, Sonneratia alba, Lumnitzera racemosa, and Nypa frutican. The riverside station was dominated by Xylocarpus granatum (ranging $\varnothing 1.36-23.25 \mathrm{~cm}$ ), while Rhizophora apiculata dominated the station inside the forest (ranging $\varnothing_{01} .27-23.25 \mathrm{~cm}$ ). The rates of mangrove growth varied among the species, with Avicennia marina as the greatest. Our result showed that the mean of mangrove biomass in the study site was $596.56 \mathrm{Mg} \mathrm{ha}^{-1}$ with carbon stock potential of $285.24 \mathrm{Mg} \mathrm{C} \mathrm{ha}^{-1}$. Mangroves inside the forests stored more carbon (332.9 $\mathrm{Mg} \mathrm{C} \mathrm{ha}^{-}{ }^{1}$ ) than ones in the riverside $\left(237.58 \mathrm{Mg} \mathrm{C}^{-1}{ }^{1}\right)$. We estimated that the destruction of one hectare of mangrove forest in the study site can potentially release $1046.83 \mathrm{CO}_{2}$, which is equivalent to $\mathrm{CO}_{2}$ released from 524.82 tonnes of burned coals.
\end{abstract}

Keywords: Biomass, carbon stock, mangrove forest, Dumai, Riau 


\section{PENDAHULUAN}

Hutan mangrove merupakan komunitas vegetasi yang ditemukan di pantai tropis dan subtropis, yang didominasi oleh jenis pohon yang mampu tumbuh dan berkembang di daerah intertidal yang tergenang air laut secara berkala dan mendapatkan masukan air tawar, sehingga mangrove banyak ditemukan di teluk yang dangkal, estuari, delta dan juga pantai yang terlindung [1].

Mangrove merupakan salah satu ekosistem inti di pesisir, selain terumbu karang dan lamun, yang menyediakan beragam jasa ekosistem (ecosystem services) dan fungsi ekologis penting, antara lain sebagai tempat ikan dan biota laut memijah dan mencari makan, pengatur kualitas air, penyedia kayu dan produk non kayu untuk masyarakat lokal, sumber keanekaragaman hayati termasuk menjadi habitat biota langka dan terancam punah [2]. Sebanyak 75\% jenis ikan komersial menghabiskan sebagian siklus hidupnya di area mangrove. Fungsi ekologis mangrove lainnya adalah melindungi wilayah pesisir dari badai dan tsunami [3] serta sebagai penyerap karbon terbesar di wilayah hutan tropis [4]. Indonesia merupakan negara yang memiliki hutan mangrove terluas di dunia, yaitu sekitar 3.12 juta ha atau $22 \%$ dari total mangrove dunia [5]. Dengan luasan tersebut, hutan mangrove Indonesia menyimpan sekitar $3 \mathrm{Pg} \mathrm{C}$ sehingga Indonesia merupakan negara penyimpan karbon biru tertinggi di dunia [6]

Sejak tahun 2005, Balai Riset dan Observasi Laut (BROL) melakukan kajian mangrove yang bertujuan untuk memahami dinamika ekosistem mangrove, yang sesuai dengan isu terkini seperti perubahan iklim. Pada tahun 2011, BROL mulai membangun stasiun monitoring mangrove di Perancak Bali untuk memantau dinamika ekosistem mangrove sekaligus pemahaman fungsi mangrove dalam mitigasi dan adaptasi perubahan iklim. Untuk meningkatkan pemahaman karakteristik ekosistem dan fungsi berdasarkan tipe hutan mangrove, BROL membangun stasiun monitoring di lokasi lainnya, yaitu Nusa Lembongan dan Dumai Riau. Ekosistem mangrove di Perancak dan Dumai memiliki karakteristik estuarine mangrove, sedangkan Nusa Lembongan bertipe fringe mangrove. Kegiatan pengukuran ang dilakukan stasiun monitoring meliputi parameter geomorfologi, vegetasi, dan hidrologi.

Tulisan ini merupakan hasil studi yang dilakukan di stasiun mangrove Dumai, Riau pada tahun 2015-2016, dengan fokus hasil kegiatan monitoring vegetasi hutan mangrove yaitu biomasa dan pertumbuhan mangrove. Lokasi studi merupakan hutan mangrove di Kota Dumai yang terdapat di pesisir Sumatra timur dengan karakteristik tanah gambut (peat) yang kaya akan karbon organik [7]. Namun, laju kerusakan hutan mangrove di wilayah ini sangat tinggi sehingga mendapatkan perhatian dalam isu karbon biru Indonesia (Ilman et al,2016). Konversi hutan mangrove menjadi lahan lainnya dapat menyebabkan terlepasnya $\mathrm{CO}_{2}$ yang tersimpan dalam bentuk biomasa mangrove maupun di dalam tanah. Dengan memanfaatkan data monitoring mangrove, studi ini bertujuan memberikan informasi potensi karbon biru yang tersimpan dalam biomasa mangrove, yang meliputi tegakan (aboveground) dan akar (belowground).

\section{METODE}

\section{Deskripsi lokasi studi}

Lokasi studi berada di Stasiun Kelautan Universitas Riau yang terletak di sekitar Sungai Mesjid, kawasan pesisir Kota Dumai (1 ${ }^{\circ} 23^{\prime} 00^{\prime \prime}$ - $1^{\circ} 24^{\prime} 23^{\prime \prime}$ LU dan 101 $23^{\circ} 37^{\prime \prime}$ $101^{\circ} 28^{\prime} 13^{\prime \prime}$ BT). Wilayah ini relatif terlindung oleh pulau-pulau kecil, salah satunya adalah Pulau Rupat. Berbatasan langsung dengan Selat Malaka yang menghubungkan Indonesia dengan negara tetangga Singapura, wilayah ini menjadi cukup ramai dengan lalu lintas kapal dan kegiatan kepelabuhan. Perairan di sekitar lokasi penelitian dipengaruhi oleh pasang surut bertipe semi-diurnal dengan ketinggian 0.5-3 $\mathrm{m}$ [8]. Berdasarkan interpretasi data citra satelit tahun 2008, kawasan mangrove di pesisir Pantai Dumai seluas 5863.32 ha dengan keragaman jenis sebanyak 17 mangrove sejati dan 18 mangrove asosiasi [9], [10]. 


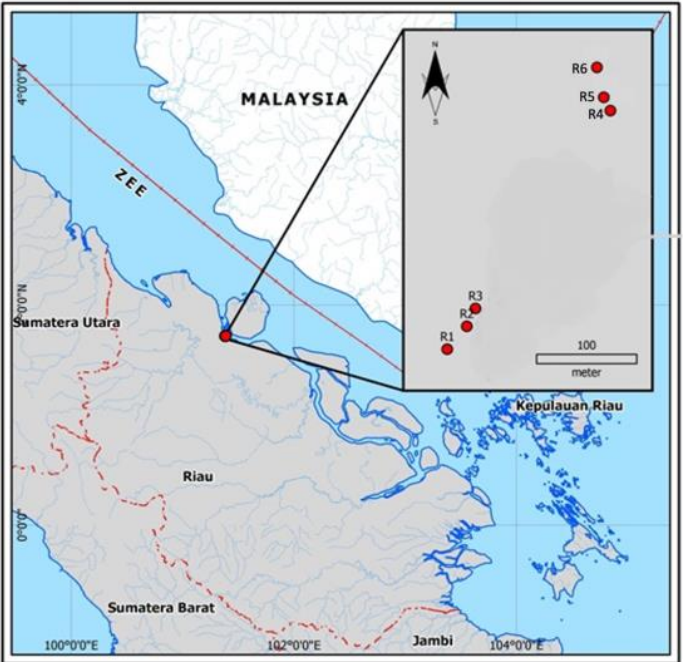

Gambar 1. Lokasi studi yang dibagi menjadi dua stasiun: tepi sungai (R1-R3) dan dalam hutan (R4-R6)

\section{Pengambilan data lapangan}

Pengambilan data dilakukan pada Februari dan Maret 2015 di dua stasiun dengan tiga substasiun di masing-masing stasiun sebagai replikasi untuk mendapatkan nilai rata-rata data per stasiun. Terdapat enam substasiun pengambilan data, tiga diantaranya mewakili Stasiun Tepi Sungai (R1-R3) dan tiga lainnya mewakili Stasiun Dalam Hutan (R4 - R6) (Gambar 1). Di setiap substasiun diaplikasikan plot lingkaran dengan radius $10 \mathrm{~m}$ dengan pengambilan data, antara lain jenis dan jumlah individu, Diameter Breast Height (DBH) batang utama, tinggi pohon (jika memungkinkan), serta lokasi atau ID [11]. Di dalam plot, seluruh pohon dengan $\mathrm{DBH} \geq 5$ $\mathrm{cm}$ dihitung, sedangkan pohon berdiameter $<5$ $\mathrm{cm}$ hanya diukur dalam radius $2 \mathrm{~m}$ dari titik pusat. Mekanisme pengambilan data di setiap substasiun mengadopsi metode menurut [12].

Tabel 1. Struktur komunitas vegetasi mangrove di lokasi penelitian berdasarkan literatur [13] dan observasi lapang

\begin{tabular}{cll}
\hline No & \multicolumn{1}{c}{ Jenis } & \multicolumn{1}{c}{ Nama Daerah } \\
\hline 1 & Acrosticum aurum ${ }^{a}$ & Piai raya \\
2 & Avicennia alba & Api-api mangi-mangi putih \\
3 & Avicennia marina & Api-api \\
4 & Bruguiera gymnorrhiza & Tanjang \\
5 & Bruguiera hainesii & \\
6 & Bruguiera parviflora & Tagar, tegar \\
7 & Ceriops tagal & Buta-buta \\
8 & Excoecaria agallocha & \\
9 & Heritiera littoralis & Tarumtum \\
10 & Lumnitzera littorea & Nipah \\
11 & Nypa fructicans & Bakau minyak, bakau akik \\
12 & Rhizophora apiculata & Bakau hitam, bakau merah \\
13 & Rhizophora mucronata & \\
14 & Rhizophora stylosa & Cigam, perepat lanang \\
15 & Scyphiphora hydrophyllacea & Pedada, kedabu, prepat \\
16 & Sonneratia alba & \\
17 & Sonneratia ovata & Nyireh, nyirih \\
18 & Xylocarpus granatum & \\
19 & Xylocarpus molluccensis & \\
\hline
\end{tabular}

a, b Tidak terdapat dalam [13]

Pertumbuhan pohon mangrove diukur menggunakan dendrometer band, yaitu gelang yang dipasang di tegakan pohon setinggi DBH (Gambar 2). Dendrometer dipasang pada empat pohon di setiap stasiun yang dipilih secara acak dan meliputi tiga jenis mangrove, yaitu Rhizophora apiculata, Xylocarpus granatum dan Avicennia marina (Gambar 2). Jenis tersebut adalah jenis dominan yang ditemukan di lokasi studi. Pengukuran dilakukan secara periodik selama 12 bulan, yaitu Juni 2015 hingga Mei 2016. 

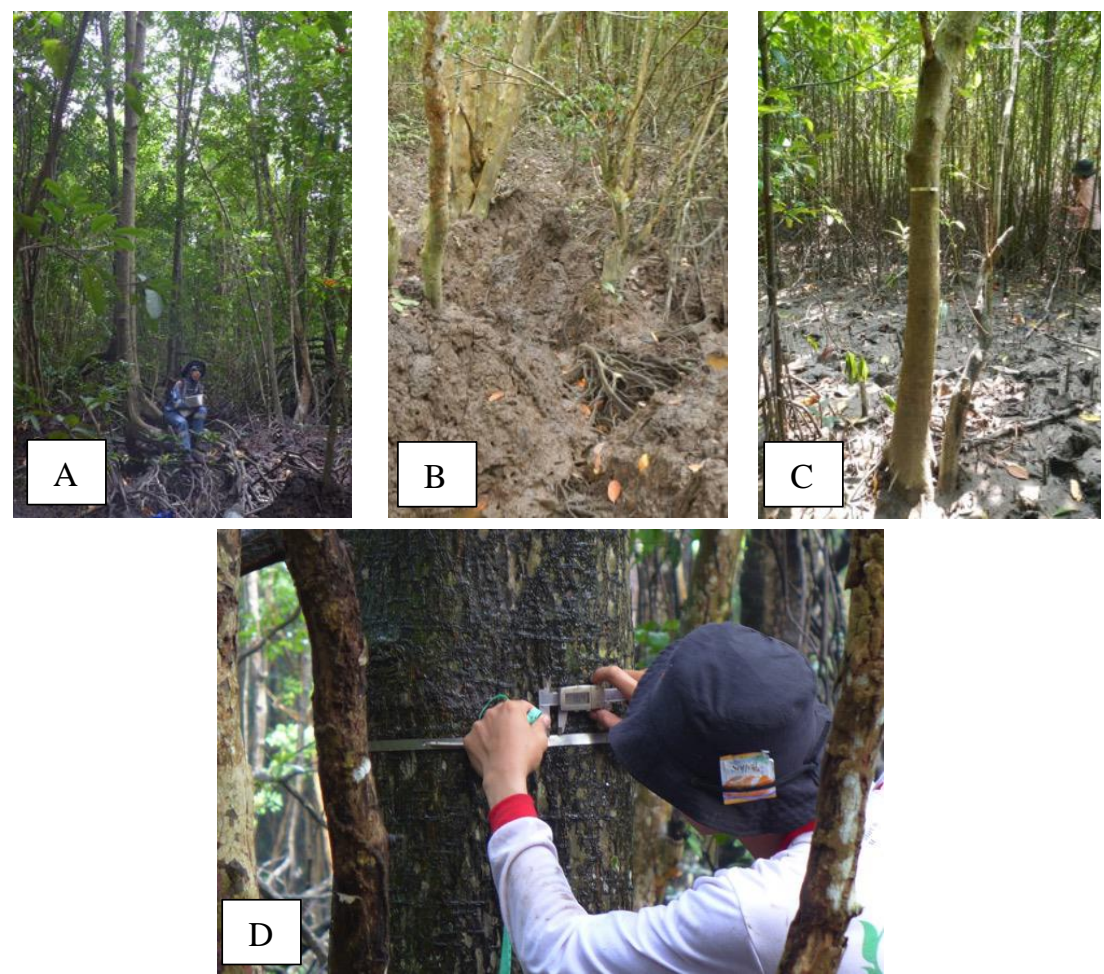

Gambar 3. Pengukuran pertambahan DBH menggunakan dendrometer band (D) pada tiga jenis mangrove: Rhizophora apiculate (A), Xylocarpus granatum (B), dan Avicennia marina (C)

\section{Analisa data}

Struktur komunitas mangrove diketahui dengan menghitung kerapatan relatif (KR), frekuensi relatif (FR), dominansi relatif (DR), dan Indeks Nilai Penting (INP) menggunakan persamaan Shannon-Wiener Index [14], [15]. Pendugaan karbon biru dilakukan di kedua kantong karbon biomasa yang tersimpan di atas (tegakan) dan dibawah tanah (akar) menggunakan persamaan alometrik yang berbasis DBH (batang pohon). Biomasa ini didefinisikan sebagai jumlah total dari material hidup di suatu kantong karbon yang dinyatakan dalam satuan ton atau Megagram per unit luas [16]. Mekanisme pengambilan data struktur komunitas mangrove dan biomasa pohon di setiap substasiun mengadopsi metode menurut [12]. Seperti pada [17] [12], hanya pohon dengan $\mathrm{DBH} \geq 5 \mathrm{~cm}$ saja yang diperhitungkan dalam estimasi biomasa dan stok karbon dalam penelitian ini.
Densitas kayu atau wood density $(\rho)$ mangrove berbeda-beda berdasarkan pada jenisnya. Dalam penelitian ini, penentuan densitas kayu mengacu pada Tabel 2 dan untuk jenis-jenis yang tidak terdapat pada protokol dilakukan penelusuran pada laman http://db.worldagroforestry.org/wd. Diameter (D) yang digunakan pada persamaan alometrik merupakan diameter setinggi dada (DBH). Nilai stok karbon setiap jenis mangrove dihitung dengan mengalikan nilai biomasanya dengan faktor konversi 0.47 [12]. Biomasa dan nilai karbon per stasiun adalah hasil penjumlahan biomasa dan nilai karbon jenis yang terdapat di masing-masing stasiun. Nilai karbon keseluruhan dikalikan dengan 3.67 untuk mengetahui emisi karbon $\left(\mathrm{CO}_{2}\right)$ yang akan terlepas ke atmosfer jika hutan mangrove di lokasi penelitian hilang atau rusak. 
Tabel 2. Persamaan alometrik dan wood density $(\rho)$ yang digunakan dalam penelitian ini dengan mengacu pada literatur.

\begin{tabular}{lcc}
\hline \multicolumn{1}{c}{ Jenis } & Persamaan Alometrik & Wood Density $(\rho)$ \\
\hline & Biomasa Bagian Atas $\left(\mathbf{A G B}^{\mathbf{a}}\right)$ & \\
Avicennia marina & $A G B=0.185 D^{2.352}[18]$ & $0.62[12]$ \\
Sonneratia alba & $A G B=0.3841 D^{2.101} \rho[19]$ & $0.47[12]$ \\
Rhizophora apiculata & $A G B=0.0695 D^{2.644} \rho[19]$ & $0.87[12]$ \\
Xylocarpus granatum & $A G B=0.1832 D^{2.21}[20]$ & $0.61[12]$ \\
Bruguiera gymnorrhiza & $A G B=0.0754 D^{2.505}[15]$ & $0.81[12]$ \\
Lumnitzera racemosa & $A G B=0.184 D^{2.384}[21]$ & $0.83[12]$ \\
& Biomasa Bagian Bawah $\left(\mathbf{B G B}^{\mathbf{b}}\right)$ & \\
Persamaan umum & $B G B=0.199 \rho^{0.8999} D^{2.22}[17]$ & \\
\hline${ }^{a}$ Above Ground Biomass; ${ }^{\mathrm{b}}$ Below Ground Biomass
\end{tabular}

\section{HASIL DAN PEMBAHASAN}

\section{Struktur komunitas mangrove}

Secara umum, hasil identifikasi di dalam plot penelitian menemukan enam jenis mangrove, yaitu Rhizophora apiculata, Avicennia marina, Xylocarpus granatum, Bruguiera gymnorrhiza, Sonneratia alba, Lumnitzera racemosa, dan Nypa frutican. Jenis mangrove di lokasi penelitian tidak seberagam di Tanjung Api-Api, Sumatera Selatan, yaitu sembilan jenis [22] dan sama dengan yang dijumpai di Taman Nasional Sembilang, namun dengan dominansi jenis yang berbeda (Rhizophora apiculata dan Bruguiera gymnorriza) [23]. Hasil kajian [13], di pesisir Kota Dumai terdapat 17 jenis mangrove (Tabel 1), sehingga 35\% dari jumlah tersebut dapat ditemukan di lokasi penelitian.

Stasiun Tepi Sungai didominasi oleh Xylocarpus granatum dengan kisaran diameter 1.36-23.25 cm, sementara stasiun di dalam hutan didominasi jenis Rhizophora apiculata berdiameter antara 1.27-23.25 cm. Kedua jenis tersebut memiliki distribusi yang cukup luas karena dapat ditemukan di seluruh substasiun (Tabel 4). Rhizophora apiculata memiliki kemampuan adaptasi yang lebih baik dibandingkan dengan jenis lainnya, sehingga memiliki kawasan yang luas untuk hidup hingga ke wilayah pedalaman (darat) selama masih mendapatkan suplai air asin [24].

Pada Tabel 4 dapat dilihat bahwa jenis yang ditemukan di Stasiun Tepi Sungai lebih beragam dibandingkan di dalam hutan. Jenis Avicennia marina, Bruguiera gymnorrhiza dan Nypa frutican hanya dijumpai di Stasiun Tepi Sungai, sementara Sonneratia alba ditemukan di Stasiun Dalam Hutan. Menurut [1], zonasi mangrove yang terbentuk di Indonesia dari laut ke darat, adalah vegetasi Avicennia yang berasosiasi dengan vegetasi Sonneratia. Vegetasi Rhizophora dan Bruguiera berada di tengah zonasi mangrove, sedangkan vegetasi Nypa berada dekat darat karena dipengaruhi oleh air tawar. Mangrove di lokasi penelitian merupakan hutan sekunder [25], sehingga komposisi jenis berdasarkan zona alami tidak lagi terlihat jelas. Jenis yang biasanya menempati zona darat ditemukan di Stasiun Tepi Sungai, seperti Xylocarpus granatum. Jenis ini biasanya menempati zona yang memiliki elevasi permukaan tanah lebih tinggi [24].

Tabel 4. Distribusi jenis mangrove di lokasi penelitian

\begin{tabular}{|c|c|c|c|c|c|c|c|}
\hline \multirow{2}{*}{ No } & \multirow{2}{*}{ Jenis } & \multicolumn{3}{|c|}{ Tepi Sungai } & \multicolumn{3}{|c|}{ Dalam Hutan } \\
\hline & & R1 & $\mathbf{R 2}$ & $\mathbf{R 3}$ & R4 & $\mathbf{R 5}$ & R6 \\
\hline 1 & Rhizophora apiculata $(R a)$ & $\checkmark$ & $\checkmark$ & $\checkmark$ & $\checkmark$ & $\checkmark$ & $\checkmark$ \\
\hline 2 & Avicennia marina $(\mathrm{Am})$ & $\checkmark$ & & & & & \\
\hline 3 & Xylocarpus granatum $(X g)$ & $\checkmark$ & $\checkmark$ & $\checkmark$ & $\checkmark$ & $\checkmark$ & $\checkmark$ \\
\hline 4 & Bruguiera gymnorrhiza (Bg) & & $\checkmark$ & & & & \\
\hline 5 & Sonneratia alba $(\mathrm{Sa})$ & & & & $\checkmark$ & & \\
\hline 6 & Nypa fruticans $(N f)$ & $\checkmark$ & & & & & \\
\hline
\end{tabular}


Berdasarkan Tabel 5, terdapat dominansi jenis di kedua stasiun penelitian. Rhizophora apiculata merupakan jenis yang mendominasi di Stasiun Dalam Hutan yang ditandai dengan INP yang paling tinggi dibandingkan dengan jenis lainnya $(\mathrm{INP}=170.71 \%)$. Sementara itu, di Stasiun Tepi Sungai didominasi oleh jenis Xylocarpus granatum dengan nilai INP sebesar 159.29\%. Meskipun Xylocarpus granatum memiliki rata-rata diameter yang lebih kecil dibandingkan Rhizophora apiculata, namun memiliki kerapatan atau kepadatan individu yang tinggi. Jenis yang memiliki kepadatan tinggi maka akan memiliki INP yang juga tinggi [26]. INP menunjukan tingkat dominansi suatu jenis di suatu area ekosistem. Jenis yang memiliki dominansi paling rendah di Stasiun Tepi Sungai adalah Avicennia marina $(\mathrm{INP}=34.36 \%$ ) dan $S$. alba di Stasiun Dalam Hutan (INP $=70.17 \%)$.

Tabel 5. Struktur vegetasi mangrove di lokasi penelitian

\begin{tabular}{|c|c|c|c|c|c|c|c|c|c|c|c|}
\hline Stasiun & $\begin{array}{c}\text { Sub } \\
\text { stasiun }\end{array}$ & Jenis & $\mathbf{N}$ & $\begin{array}{l}\mathrm{DBH}^{\mathrm{a}} \\
(\mathrm{cm})\end{array}$ & $\begin{array}{c}\text { Kisaran } \\
\text { DBH } \\
(\mathbf{c m}) \\
\end{array}$ & $\begin{array}{c}\text { Bassal } \\
\text { Area }\end{array}$ & $\begin{array}{c}\mathbf{K}^{\mathbf{b}} \\
(\mathbf{p h n} / \mathbf{h a})\end{array}$ & $\begin{array}{l}\mathbf{K R}^{\mathbf{c}} \\
(\%)\end{array}$ & $\begin{array}{l}\mathbf{F R}^{\mathbf{d}} \\
(\%)\end{array}$ & $\begin{array}{l}\mathrm{DR}^{\mathrm{e}} \\
(\%)\end{array}$ & INP $^{f}$ \\
\hline \multirow{12}{*}{$\begin{array}{l}\text { Tepi } \\
\text { Sungai }\end{array}$} & R1 & $R a$ & 26 & 5.70 & $5.10 \pm 6.37$ & 25.47 & 827.24 & 75.71 & 25 & 11.75 & 112.46 \\
\hline & & $A m$ & 16 & 10.71 & $5.73 \pm 21.34$ & 90.04 & 509.07 & 13.33 & 25 & 41.53 & 79.86 \\
\hline & & $X g$ & 8 & 9.99 & $6.05 \pm 14.65$ & 78.34 & 254.53 & 9.52 & 25 & 36.13 & 70.66 \\
\hline & & $L r$ & 1 & 5.41 & $0 \pm 2.71$ & 22.98 & 31.82 & 1.96 & 25 & 10.60 & 37.56 \\
\hline & $\mathrm{R} 2$ & $R a$ & 41 & 13.07 & $5.73 \pm 23.25$ & 134.10 & 1304.49 & 41.23 & 25 & 42.97 & 109.20 \\
\hline & & $X g$ & 48 & 9.49 & $5.73 \pm 15.29$ & 70.70 & 1527.20 & 55.26 & 25 & 22.65 & 102.92 \\
\hline & & $B g$ & 2 & 10.19 & $7.96 \pm 12.42$ & 81.51 & 63.63 & 2.63 & 25 & 26.12 & 53.75 \\
\hline & & $A m$ & 1 & 5.73 & $5.73 \pm 5.73$ & 25.77 & 31.82 & 1.10 & 25 & 8.26 & 34.36 \\
\hline & $\mathrm{R} 3$ & $R a$ & 25 & 12.41 & $7 \pm 19.43$ & 120.90 & 795.42 & 24.78 & 50 & 65.94 & 140.71 \\
\hline & & $X g$ & 74 & 8.92 & $5.41 \pm 17.83$ & 62.46 & 2354.44 & 75.22 & 50 & 34.06 & 159.29 \\
\hline & Rata-rata & & & 9.16 & & & & & & & \\
\hline & Kisaran & & & $\begin{array}{l}5.41- \\
13.07 \\
\end{array}$ & & & & & & & \\
\hline \multirow{9}{*}{$\begin{array}{l}\text { Dalam } \\
\text { Hutan }\end{array}$} & $\mathrm{R} 4$ & $R a$ & 53 & 14.06 & $6.69 \pm 21.34$ & 155.18 & 1686.29 & 72.97 & 33.3 & 39.68 & 145.99 \\
\hline & & $S a$ & 3 & 11.68 & $11.15 \pm 12.74$ & 107.09 & 95.45 & 9.46 & 33.3 & 27.38 & 70.17 \\
\hline & & $X g$ & 9 & 12.81 & $6.69 \pm 20.70$ & 128.82 & 286.35 & 17.57 & 33.3 & 32.94 & 83.84 \\
\hline & $\mathrm{R} 5$ & $R a$ & 28 & 11 & $5.19 . \pm 29.05$ & 94.99 & 890.87 & 65.71 & 50 & 55.00 & 170.71 \\
\hline & & $X g$ & 6 & 9.95 & $5.54 \pm 12.90$ & 77.72 & 190.90 & 34.29 & 50 & 45.00 & 129.29 \\
\hline & R6 & $R a$ & 16 & 15.07 & $5.10 \pm 36.62$ & 178.28 & 509.07 & 20.51 & 50 & 61.40 & 131.91 \\
\hline & & $X g$ & 61 & 11.95 & $5.41 \pm 23.25$ & 112.10 & 1940.82 & 79.49 & 50 & 38.60 & 168.09 \\
\hline & Rata-rata & & & 11.62 & & & & & & & \\
\hline & Kisaran & & & $\begin{array}{l}\text { 9.95- } \\
15.07\end{array}$ & & & & & & & \\
\hline
\end{tabular}

${ }^{a}$ Diameter Breast Height (diameter setinggi dada); ${ }^{\mathrm{b}}$ Kerapatan; ${ }^{\mathrm{c}}$ Kerapatan Relatif; ${ }^{\mathrm{d}}$ Frekuensi Relatif; ${ }^{\mathrm{e}}$ Dominansi Relatif; ${ }^{\mathrm{f}}$ Indeks Nilai Penting;

Am: Avicennia marina; Bg: Bruguiera gymorrhiza; Ra: Rhizophora apiculata, Sa Sonneratia alba, Xg: Xylocarpus granatum)

\section{Pertumbuhan mangrove}

Kesesuaian kondisi lingkungan terhadap mangrove dapat dinilai dari laju pertumbuhan mangrove. Dari hasil monitoring yang terlihat dalam Gambar 4 dan Tabel 5. Pertumbuhan mangrove di lokasi studi., species Rhizophora apiculata memiliki laju pertumbuhan yang lebih cepat dibandingkan dengan Xylocarpus granatum. Pada lokasi tepi sungai Avicennia marina yang memiliki pertumbuhan cukup baik dengan rata-rata pertambahan diameter $1.78 \mathrm{~cm}$ tahun $^{-1}$. Kondisi substrat dan elevasi permukaan tanah terhadap pasang surut dapat menjadi faktor yang memberikan kondisi optimal untuk tumbuh.

Secara umum, tipe substrat pantai Kota Dumai adalah lumpur berlempung, yaitu didominasi oleh fraksi lumpur hingga 84.12\%, sementara fraksi lempung dan pasir hanya sekitar 12.26\% (lempung) dan 3.62\% [27]. Rhizophora apiculata merupakan jenis dominan di Kota Dumai dimana jenis ini tumbuh subur di pesisir bertipe lumpur [27]. Kesesuaian substrat dan tinggi pasang surut menyebabkan jenis mangrove ini dapat tumbuh dengan baik, dengan laju pertambahan 
diameter batang pohon $1.08-1.09 \mathrm{~cm}^{-1 a h u n^{-1}}$.

Selain Rhizophora apiculata, Xylocarpus granatum merupakan jenis mangrove lain yang dominan di lokasi studi. Data pengamatan ini sesuai dengan studi yang dilakukan oleh Roza (2016) yang menjumpai Xylocarpus granatum sebagai jenis dominan di lokasi studi (9408 ind ha $^{-1}$ ), melebihi dari Rhizophora apiculata (5098 ind $\mathrm{ha}^{-1}$ ). Dibandingkan dengan Avicennia marinadan Rhizophora apiculata, Xylocarpus granatum memiliki laju pertumbuhan yang lebih rendah, yaitu berkisar antara $0.49-0.80 \mathrm{~cm}$ tahun $^{-1}$.
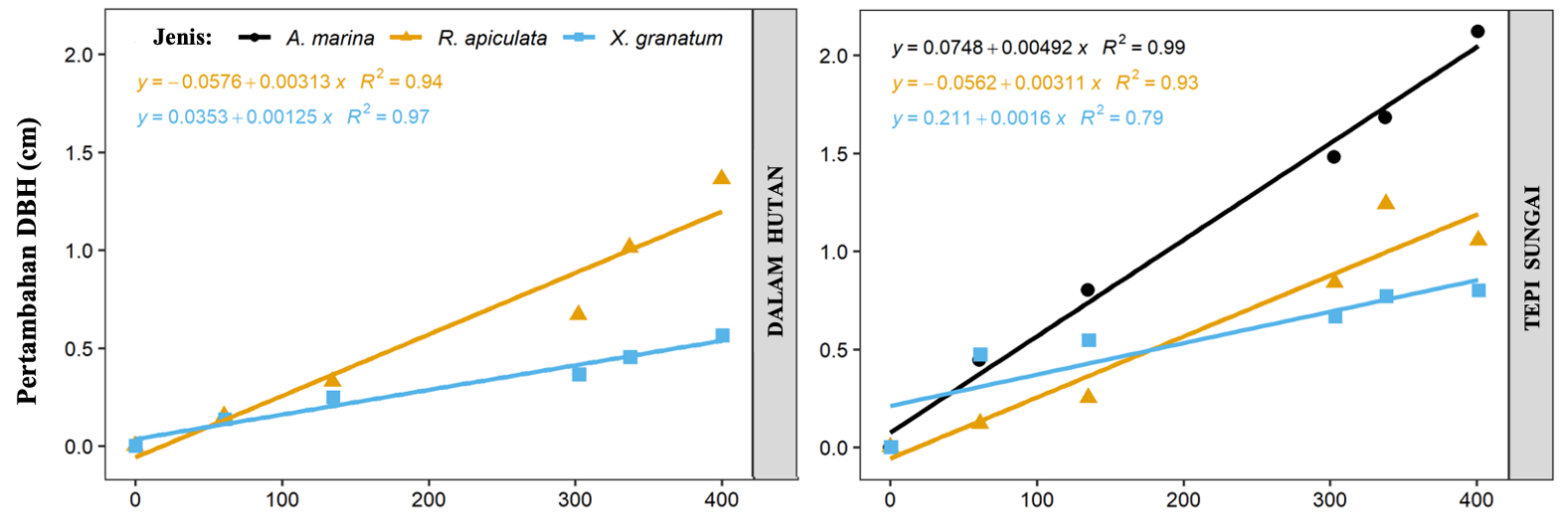

Waktu (Hari)

Gambar 4. Pertumbuhan mangrove berdasarkan species yang dominan di hutan mangrove Dumai, yaitu Rhizophora apiculata, Xylocarpus granatumdan Avicennia marina. Pengukuran dilakukan pada bulan Juni 2015, Agustus 2015, 30 Januari 2016, Maret 2016 dan Mei 2016

Tabel 5. Pertumbuhan mangrove di lokasi studi.

\begin{tabular}{ccccccc}
\hline Species & $\begin{array}{c}\text { Dalam hutan } \\
\text { Diameter } \\
\text { awal }\end{array}$ & $\begin{array}{c}\text { Diameter } \\
\text { akhir }\end{array}$ & $\begin{array}{c}\text { Rata-rata } \\
\text { pertumbuhan } \\
\text { (cm/tahun) }\end{array}$ & $\begin{array}{c}\text { Tepi sungai } \\
\text { Diameter } \\
\text { awal }\end{array}$ & $\begin{array}{c}\text { Rata-rata } \\
\text { Diameter } \\
\text { akhir }\end{array}$ & $\begin{array}{c}\text { pertumbuhan } \\
\text { (cm/tahun) }\end{array}$ \\
\hline$A m$ & - & - & - & 12.1 & 13.8 & 1.87 \\
$R a$ & 22.3 & 23.4 & 1.09 & 12.4 & 14.1 & 1.08 \\
$X g$ & 14.0 & 14.2 & 0.49 & 13.8 & 14.6 & 0.80 \\
\hline
\end{tabular}

Am: Avicennia marina, Ra: Rhizophora apiculata, Xg: Xylocarpus granatum

Pengamatan pertumbuhan pohon mangrove (pertambahan diameter) secara berkala dalam suatu plot permanen merupakan aspek penting untuk memantau tidak hanya kondisi vegetasinya, tetapi juga dinamika cadangan karbonnya (carbon sequestration) yang tersimpan dalam pohon sebagai material hidup [23].

\section{Biomasa dan Potensi Simpanan karbon}

Terdapat banyak kantong biomasa dan karbon di suatu hutan mangrove, di bawah permukaan tanah (sedimen dan akar) maupun di atas permukaan tanah (daun, cabang, batang, ranting, woody debris, dll) [11], [12]. Di hutan mangrove, pohon mendominasi kantong karbon di atas permukaan tanah, baik keberadaannya maupun kondisinya dapat menjadi indikator perubahan penggunaan lahan dan kondisi ekologi. Hasil penghitungan menggunakan persamaan alometrik pada Tabel 6, diperoleh bahwa biomasa pohon mangrove di lokasi penelitian bervariasi antar substasiun, berkisar antara $71.85 \mathrm{Mg} \mathrm{ha}^{-1}$ (R1) hingga $289.52 \mathrm{Mg} \quad$ ha $^{-1} \quad$ (R6). Bila diperhitungkan ke massa karbon, maka biomasa yang tersimpan sekitar $33.77 \mathrm{Mg}$ $\mathrm{C} \mathrm{ha}^{-1}$ hingga $144.86 \mathrm{Mg} \mathrm{C}^{-1}$. Biomasa dan stok karbon tertinggi terdapat di substasiun R6 yang berada di Stasiun Dalam Hutan dan terendah ada di Substasiun R1 yang letaknya di Stasiun Tepi Sungai. Berdasarkan jenis, kontributor terbesar terhadap potensi biomasa dan karbon stok di Hutan Mangrove Dumai 
adalah Rhizophora apiculata dan Xylocarpus granatum.

Tabel 6. Biomasa dan stok karbon di lokasi penelitian.

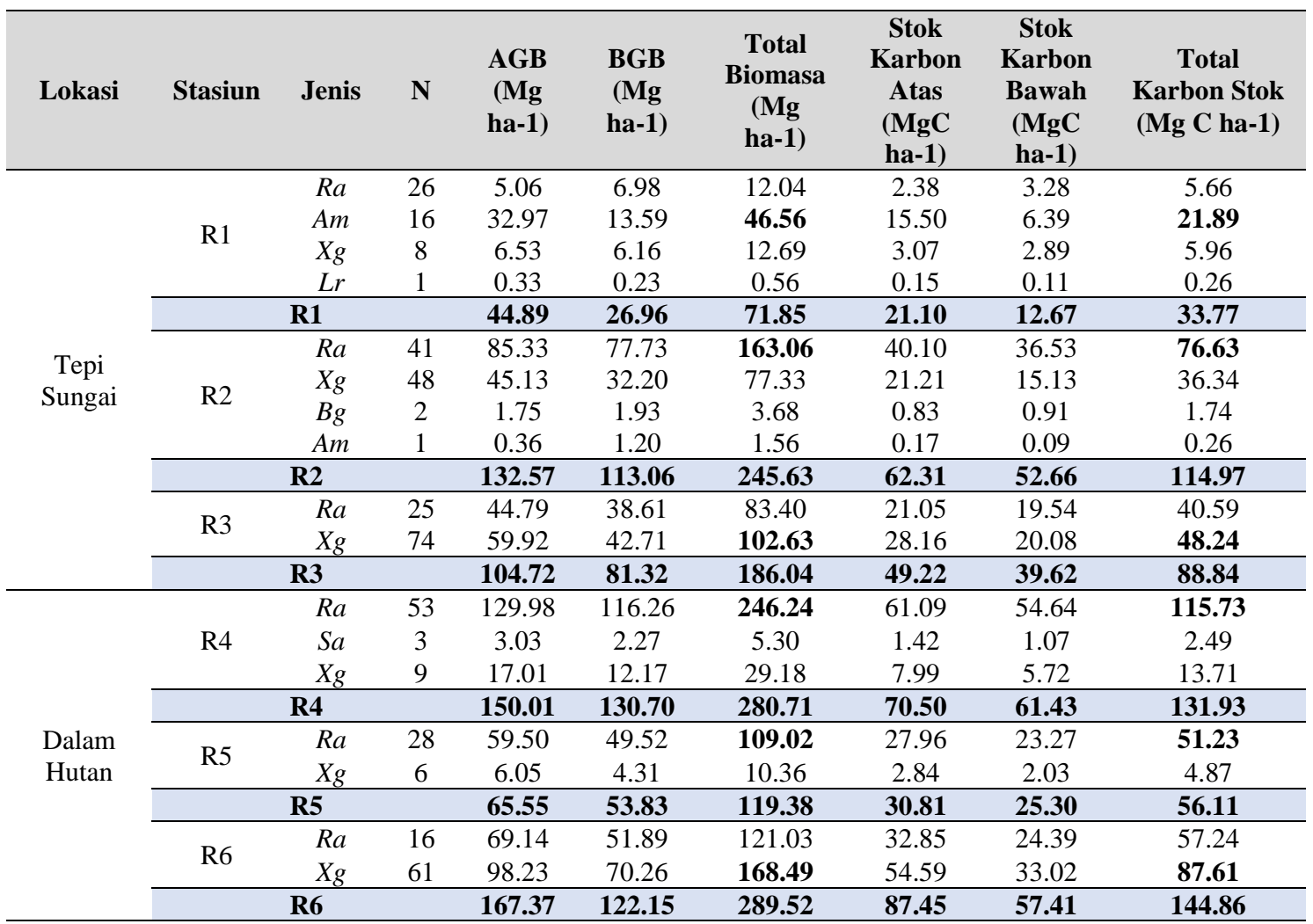

Keterangan: Am: Avicennia marina, Bg: Bruguiera gymorrhiza, Ra: Rhizophora apiculata, Sa: Sonneratia alba, Xg: Xylocarpus granatum

Secara keseluruhan, pada Gambar 3 dapat diketahui bahwa biomasa di atas permukaan tanah lebih besar $\left(94.06 \mathrm{Mg} \mathrm{ha}^{-1}\right.$ di Substasiun Tepi Sungai dan $127.64 \mathrm{Mg} \mathrm{ha}^{-1}$ di Substasiun Dalam Hutan) dibandingkan dengan di bawah permukaan tanah $\left(73.78 \mathrm{Mg} \mathrm{ha}^{-1}\right.$ di Substasiun Tepi Sungai dan $102.23 \mathrm{Mg} \mathrm{ha}^{-1}$ di Substasiun Dalam Hutan). Begitupula dengan nilai stok karbonnya. Nypa fruticans tidak diperhitungkan dalam estimasi biomasa dan karbon stok dalam penelitian ini, sehingga total yang tertera pada Gambar 3 belum termasuk kontribusi dari jenis mangrove tersebut. 


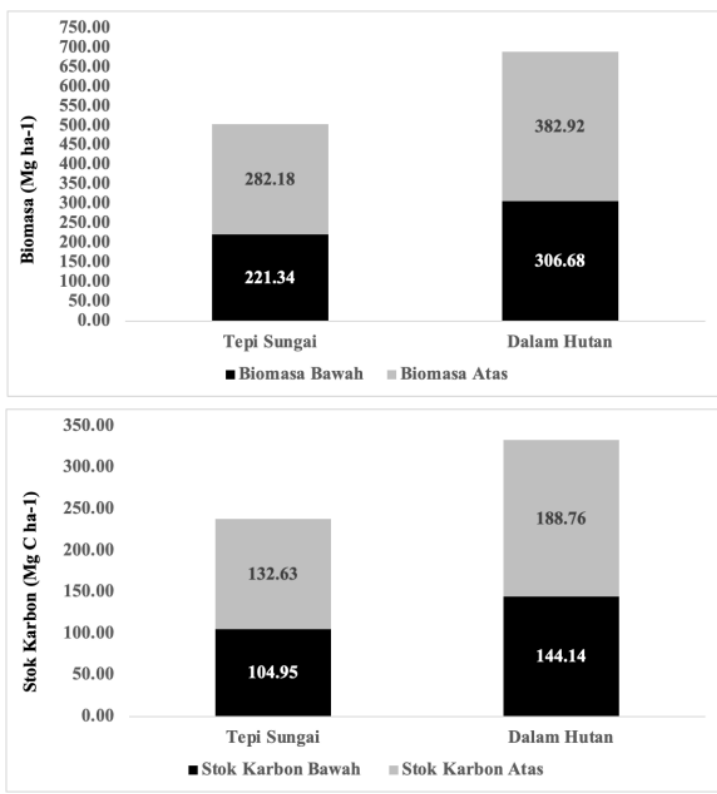

Gambar 5. Potensi biomasa dan stok karbon di lokasi penelitian

Tingginya nilai rata-rata biomasa dan potensi stok karbon mangrove di Stasiun Dalam Hutan salah satunya dipengaruhi oleh rata-rata DBH pohon yang jauh lebih besar $(11.65 \mathrm{~cm})$ dibandingkan di Stasiun Tepi Sungai $(9.16 \mathrm{~cm})$ (Tabel 5). Persamaan alometrik yang digunakan dalam penelitian ini berbasis pada DBH pohon, sehingga pertambahan biomasa linier dengan diameter [11], [12], [26]. Nilai rata-rata biomasa dan potensi karbon di lokasi penelitian berada dalam kisaran hutan mangrove Indonesia yaitu antara 9.4 $\mathrm{Mg} \mathrm{C}^{-1}$ (Cilacap, Jawa Tengah) dan 328.4 Mg C ha-1 (Sembilang, Sumatera Selatan). Dengan nilai estimasi yang diperhitungkan dalam studi ini, hilangnya satu hektar hutan mangrove di Dumai dapat melepaskan $1046.83 \mathrm{Mg}$ ke atmosfer, atau setara dengan emisi $\mathrm{CO}_{2}$ yang dihasilkan dari pembakaran 524.82 ton batubara (https://www.epa.gov/energy/greenhouse-gasequivalencies-calculator).

Diperkirakan potensi karbon biru di lokasi penelitian ini akan lebih tinggi bila stok karbon yang tersimpan di dalam tanah turut diperhitungkan sehingga kerusakan hutan mangrove akan menghasilkan emisi $\mathrm{CO}_{2}$ lebih besar. Sebagai acuan, hutan mangrove di wilayah tropis memiliki kandungan karbon total (dari kantong karbon tanah dan biomasa) sebesar $1023 \mathrm{Mg} \mathrm{C}^{-1}$ [28]. Fungsi mangrove dalam menyimpan karbon yang sangat besar membuktikan peran mangrove dalam mitigasi perubahan iklim yang signifikan, sehingga mangrove merupakan ekosistem karbon biru yang harus dipertahankan.

\section{KESIMPULAN}

Mangrove di lokasi penelitian terdiri dari enam jenis, yaitu Rhizophora apiculata, Avicennia marina, Sonneratia alba, Xylocarpus granatum, Lumnitzera racemosa, dan Nypa fruticans, dengan dominansi tinggi jenis Rhizophora apiculata di Stasiun Dalam Hutan (INP $=170.71 \%$ ) dan Xylocarpus granatum di Stasiun Tepi Sungai (INP = $159.29 \%$ ). Biomasa pohon mangrove di lokasi penelitian bervariasi antar substasiun, dengan rata-rata $167.84 \mathrm{Mg} \mathrm{ha}^{-1}$ di tepi sungai dan $229.87 \mathrm{Mg}$ ha $^{-1}$ di dalam hutan. Bila diperhitungkan ke massa karbon, maka biomasa yang tersimpan sekitar $79.19 \mathrm{Mg} \mathrm{C}^{-}$ ${ }^{1}$ di tepi sungai dan $110.97 \mathrm{Mg} \mathrm{C} \mathrm{ha}^{-1}$ di dalam hutan. Secara keseluruhan, biomasa dan stok karbon mangrove di lokasi penelitian berturutturut sebesar 595.56 $\mathrm{Mg} \mathrm{ha}^{-1}$ dan 285.24 Mg C $\mathrm{ha}^{-1}$. Jika dikonversi dengan nilai $\mathrm{CO}_{2}$, maka satu hektar hutan mangrove di Dumai akan melepaskan $1046.83 \mathrm{Mg} \mathrm{CO}_{2}$ ke atmosfer jika hutan tersebut rusak atau bahkan hilang.

\section{UCAPAN TERIMA KASIH}

Penulis mengucapkan terima kasih kepada Balai Riset dan Observasi Laut atas pendanaan penelitian ini, yang menjadi bagian dari riset Aplikasi Sistem Adaptasi Mangrove terhadap Perubahan Iklim. Penulis juga berterima kasih kepada seluruh tim penelitian yang terlibat, terutama Hanggar Prasetio Kadarisman, I Nyoman Surana, dan Taat Mujahid Arifin yang telah membantu selama proses pengambilan data di lapangan. Terima kasih juga kepada para reviewer yang telah memberikan masukan positif bagi kebaikan tulisan ini.

\section{DAFTAR PUSTAKA}


[1] D. G. Bengen, Pedoman teknis pengenalan dan Pengelolaan Ekosistem mangrove. Bogor: Pusat Kajian Sumber Daya Pesisir dan Lautan, Institut. Pertanian Bogor., 2001.

[2] N. C. Duke et al., "A World Without Mangroves?," Science (80-. )., vol. 317, no. 5834, pp. 41b-42b, 2007, doi: 10.1126/science.317.5834.41b.

[3] W. Ohira, K. Honda, M. Nagai, and A. Ratanasuwan, "How effective were mangroves as a defence against the recent tsunami?," Trees (Berl. West), vol. 27 , no. 1, pp. 443-7, 2013, doi: $10.2307 / 2387877$.

[4] D. R. Cahoon et al., "Mass Tree Mortality Leads to Mangrove Peat Collapse at Bay Islands , Honduras after Hurricane Mitch Linked references are available on JSTOR for this article: Mass tree mortality leads to mangrove peat collapse at Bay Islands , Honduras after Hurricane M," J. Ecol., vol. 91, no. 6, pp. 1093-1105, 2003.

[5] C. Giri et al., "Status and distribution of mangrove forests of the world using earth observation satellite data," Glob. Ecol. Biogeogr., vol. 20, no. 1, pp. 154159, 2011, doi: 10.1111/j.14668238.2010.00584.x.

[6] D. M. Alongi et al., "Indonesia's blue carbon: a globally significant and vulnerable sink for seagrass and mangrove carbon," Wetl. Ecol. Manag., vol. 24 , no. 1, pp. 3-13, 2015, doi: $10.1007 / \mathrm{s} 11273-015-9446-\mathrm{y}$.

[7] R. Agung et al., Status Hutan \& Kehutanan Indonesia 2018. Jakarta, 2018.

[8] M. Alkhatib, T. C. Jennerjahn, and J. Samiaji, "Biogeochemistry of the Dumai River estuary, Sumatra ,
Indonesia , a tropical black-water river," Limnol. Oceanogr., vol. 52, no. 6, pp. 2410-2417, 2007.

[9] S. Nedi, B. Pramudya, E. Riani, and Manuwoto, "Karakteristik lingkungan perairan Selat Rupat," J. Environ. Sci., vol. 1, no. 4, pp. 25-35, 2010.

[10] E. Prianto, R. Jhonnerie, R. Firdaus, T. Hidayat, and Miswadi, "Keanekaragaman Hayati dan Struktur Ekologi Mangrove Dewasa di Kawasan Pesisir Kota Dumai - Propinsi Riau," Biodiversitas, vol. 7, no. 4, pp. 327332, 2006.

[11] UNESCO, "Coastal blue carbon," 2017, [Online]. Available: http://www.unesco.org/new/en/naturalsciences/ioc-oceans/sections-andprogrammes/ocean-sciences/oceancarbon/coastal-blue-carbon/.

[12] J. B. Kauffman and D. C. Donato, "Protocols for the measurement, monitoring and reporting of structure, biomass and carbon stocks in mangrove forests," Bogor, Indonesia, 2012.

[13] E. Prianto, R. Jhonnerie, R. Firdaus, T. Hidayat, and Miswadi, "Keanekaragaman hayati dan struktur ekologi mangrove dewasa di kawasan pesisir Kota Dumai," Biodiversitas, vol. 7, no. 4, pp. 327-332, 2006, doi: 10.13057/biodiv/d070406.

[14] F. K. Dimalen and M. J. Rojo, "Floral diversity of a mangrove forest in Cotabato City, Philippines," J. Bio. Env. Sci, vol. 13, no. 6, pp. 117-123, 2018, [Online]. Available: http://www.innspub.net.

[15] F. Kasim, M. K. Kadim, S. Nursinar, Z. Karim, and A. Lamalango, "Comparison of true mangrove stands in Dudepo and Ponelo islands, north Gorontalo district, Indonesia," 
Biodiversitas, vol. 20, no. 1, pp. 259266, 2019, doi: 10.13057/biodiv/d200142.

[16] S. Kitamura, C. Anwar, A. Chaniago, and S. Baba, Handbook of Mangroves in Indonesia: Bali and Lombok. Tokyo, Japan: International Society for Mangrove Ecosystem (ISME), 1997.

[17] A. Komiyama, S. Poungparn, and S. Kato, "Common allometric equations for estimating the tree weight of mangroves," J. Trop. Ecol., vol. 21, no. 4, pp. 471-477, 2005, doi: $10.1017 / \mathrm{S} 0266467405002476$.

[18] I. W. S. Dharmawan and C. A. Siregar, "Karbon tanah dan pendugaan karbon tegakan," Penelit. Hutan dan Konserv. Alam, vol. V, no. No.4, pp. 317-328, 2008.

[19] J. B. Kauffman and T. G. Cole, "Micronesian mangrove forest structure and tree responses to a severe typhoon," Wetlands, vol. 30, no. 6, pp. 1077-1084, 2010, doi: 10.1007/s13157-010-0114-y.

[20] M. A. Talan, "Persamaan Penduga Biomassa," 2008.

[21] A. Kangkuso et al., "Allometric models and aboveground biomass of Lumnitzera racemosa Willd. forest in Rawa Aopa Watumohai National Park, Southeast Sulawesi, Indonesia," Forest Sci. Technol., vol. 12, no. 1, pp. 43-50, 2016,

doi:

$10.1080 / 21580103.2015 .1034191$.

[22] A. I. S. Purwiyanto and F. Agustriani, "Estimasi Stok Karbon Mangrove (Aboveground) di Tanjung Api-Api, Sumatera Selatan," J. Ilmu dan Teknol. Kelaut. Trop., vol. 9, no. Desember 2017, pp. 761-770, 2017, doi: 10.29244/jitkt.v9i2.19308.
[23] S. Manuri, D. Consulting, J. Purbopuspito, and M. W. Warren, "SStock Assessment of Mangrove Ecosystem at Sembilang National Park, South Sumatera, Indonesia," 2011. doi: 10.13140/2.1.3600.8965.

[24] M. A. Kusumaningtyas et al., "Blue Carbon Stock of Mangrove Ecosystem in Nusa Penida , Bali," no. November, pp. 4-7, 2014.

[25] A. Wibowo, "Kajian Penurunan Emisi Gas Rumah Kaca Sektor Kehutanan untuk Mendukung Kebijakan Perpres No. 61 / 2011 (Review of Reducing Green House Gas Emission for Forestry Sector to Support the Policy of Presidential Regulation No. 61 / 2011)," J. Anal. Kebijak. Kehutan., vol. 10, no. 3, pp. 235-254, 2013.

[26] R. N. A. Ati et al., "Stok Karbon Dan Struktur Komunitas Mangrove Sebagai Blue Carbon Di Tanjung Lesung, Banten," J. Segara, vol. 10, no. 2, 2015, doi: 10.15578/segara.v10i2.21.

[27] S. Y. Roza, "Kontribusi mangrove dalam memerangkap sedimen di wilayah pesisir Kota Dumai Provinsi Riau," 2016.

[28] D. C. Donato, J. B. Kauffman, D. Murdiyarso, S. Kurnianto, M. Stidham, and M. Kanninen, "Mangroves among the most carbon-rich forests in the tropics," Nat. Geosci., vol. 4, no. 5, pp. 293-297, 2011, doi: $10.1038 /$ ngeo1123. 
